\title{
Decreased Superoxide Anion and Hydrogen Peroxide Production by Neutrophils and Monocytes in Human Immunodeficiency Virus-Infected Children and Adults
}

\author{
T. P. CHEN, R. L. ROBERTS, K. G. WU, B. J. ANK, AND E. R. STIEHM \\ Department of Pediatrics, Division of Allergy/Immunology: UCLA School of Medicine, \\ Los Angeles. California 90024
}

\begin{abstract}
The higher susceptibility to serious bacterial infections of patients, particularly children, infected with the human immunodeficiency virus (HIV) may be due in part to defective function of their phagocytic cells. We examined the ability of polymorphonuclear cells and monocytes of HIV-infected children and adults to generate superoxide anion (SO) and hydrogen peroxide (HP) and compared it with that of cells from normal children and adults. SO was measured by reduction of cytochrome $c$ and HP by horseradish peroxidase-dependent oxidation of phenol red. The cells were incubated in 96-well plates at $37^{\circ} \mathrm{C}$ for $2 \mathrm{~h}$ before the assay and the nonadherent cells then removed. Readings for SO were taken at 10, 30, 60, and $120 \mathrm{~min}$ after stimulation with phorbol myristate acetate; HP production was assayed after 90 min. The SO and HP production by polymorphonuclear cells and monocytes from both HIV-infected children and adults was consistently found to be markedly lower than that of cells from age-matched controls. The magnitude of the difference in response between patients and control cells also increased with increasing incubation time. Thus, phagocytic cells from HIV-infected children and adults are defective in their ability to generate reactive oxygen intermediates, and this defect may make them more vulnerable to bacterial and fungal infections. (Pediatr Res 34: 544550,1993 )
\end{abstract}

Abbreviations

HIV, human immunodeficiency virus PMN, polymorphonuclear cells SO, superoxide anion HP, hydrogen peroxide PMA, phorbol myristate acetate ADCC, antibody-dependent cellular cytotoxicity ARC, AIDS-related complex HRPO, horseradish peroxidase PRS, phenol red solution MNC, mononuclear cell NBT, nitroblue tetrazolium ROI, reactive oxygen intermediate HBSS, Hanks' balanced salt solution

Received February 11, 1993; accepted May 13, 1993.

Correspondence and reprint requests: Robert L. Roberts, M.D., Ph.D., Department of Pediatrics, 22-387 MDCC. UCLA Medical Center. Los Angeles. CA 90024-1752.

Supported in part by grants from the Pediatric AIDS Foundation (500-047. 500-127 and 770196), a Pediatric AIDS Foundation Summer Student Intern Award, and grants from the National Institutes of Health (HD-09800. AI-15332. AI-27550, and RR-00865). Dr. Roberts is a Pediatric AIDS Foundation Scholar.
HIV infection depletes the patients of their CD4 lymphocytes, accounting for their vulnerability to opportunistic infections, but more common bacterial pathogens also are a source of considerable morbidity. Bacterial infections are more likely to be fatal in HIV-infected infants and children, whereas adult patients are more likely to succumb to opportunistic infections. This increased susceptibility in pediatric patients may be due to their immune naivety and the impairment of normal immune responses caused by the virus. However, defects in their phagocytic cells may also contribute to this propensity to bacterial infections.

Previous studies have demonstrated defects in phagocytic cell function in both HIV-infected adults and children. PMN from adults infected with HIV have defects in chemotaxis and in $\mathrm{ADCC}$ that become more severe with disease progression $(1,2)$. Our laboratory recently reported that ADCC by PMN from HIVinfected children and adults is defective when using HIV antigencoated targets (3). Decreased chemotactic and bactericidal activity has also been noted in PMN from HIV-infected children even before onset of AIDS-associated symptoms (4, 5).

Investigators have also found defects in monocyte function associated with HIV infection (6). Decreased chemotaxis by monocytes from adults with AIDS or ARC was first reported in $1984(7,8)$. Monocytes from HIV-infected adults also have decreased candidacidal ability and impaired oxidative burst activity $(9,10)$. Defective monocyte accessory function for promoting lymphocyte proliferative responses has been demonstrated in HIV-infected patients (11).

The purpose of the present study was to investigate oxidative burst activity of PMN and monocytes from adult and pediatric HIV-infected patients. We examined the ability of adherent phagocytic cells of HIV-infected patients to generate SO and HP in response to PMA compared with that of normal adults and normal children. Defective oxidative burst activity was found to occur in both PMN and monocytes from both adults and children infected with HIV.

\section{MATERIALS AND METHODS}

Patient population. Adult ( $15-44$ y, $n=13)$ and pediatric (0.5$11 \mathrm{y}, n=18) \mathrm{HIV}$-infected patients were recruited from the outpatient Maternal Child Immunology Clinic, UCLA Medical Center. The patients were not acutely ill or hospitalized at the time of study. The CD4 counts of HIV-infected adults were in the range of $50-984 / \mathrm{mm}^{3}$, and those of the HIV-infected children were in the range of $11-3012 / \mathrm{mm}^{3}$ (Table 1). Those patients with a CD4 count of less than 500 were taking an antiretroviral drug. HIV infection was determined by presence of antibody or viral antigens (p24) or by viral culture. Normal adults $(n=20)$ and normal children $(1-10 \mathrm{y}, n=11)$ were used as healthy volunteers. All blood samples were obtained in accord with the 
Table 1. Patient profile

\begin{tabular}{|c|c|c|c|c|}
\hline Patient no. & Sex & Age $(y)$ & CD4 $(\%)^{*}$ & CD4 (number) $\dagger$ \\
\hline \multicolumn{5}{|l|}{ HIV-infected children } \\
\hline 1 & $\mathbf{M}$ & 0.5 & 43 & 3012 \\
\hline 2 & $\mathbf{M}$ & 0.5 & 43 & 1565 \\
\hline 3 & $\mathbf{M}$ & 1.0 & 45 & 2360 \\
\hline 4 & $\mathrm{~F}$ & 1.0 & 51 & 2196 \\
\hline 5 & $\mathrm{~F}$ & 1.0 & 30 & 990 \\
\hline 6 & $\mathrm{~F}$ & 1.0 & 41 & 1729 \\
\hline 7 & $\mathbf{M}$ & 2.0 & 34 & 2182 \\
\hline 8 & M & 3.5 & 2 & 24 \\
\hline 9 & $\mathrm{~F}$ & 3.0 & 28 & 903 \\
\hline 10 & M & 6.5 & 25 & 795 \\
\hline 11 & $\mathbf{M}$ & 6.0 & 6 & 50 \\
\hline 12 & $\mathrm{~F}$ & 7.5 & 23 & 799 \\
\hline 13 & $\mathrm{~F}$ & 8.0 & 25 & 546 \\
\hline 14 & $\mathbf{F}$ & 8.5 & 15 & 14 \\
\hline 15 & $\mathbf{M}$ & 8.5 & 3 & 11 \\
\hline 16 & $\mathbf{M}$ & 9.0 & 6 & 53 \\
\hline 17 & M & 11.0 & 39 & 618 \\
\hline 18 & M & 11.5 & 24 & 611 \\
\hline \multicolumn{5}{|c|}{$\begin{array}{l}\text { HIV-infected adolescents } \\
\text { and adults }\end{array}$} \\
\hline 1 & $\mathbf{M}$ & 15 & 27 & 328 \\
\hline 2 & M & 19 & 25 & 560 \\
\hline 3 & $F$ & 22 & 29 & 984 \\
\hline 4 & $F$ & 23 & 24 & 406 \\
\hline 5 & F & 23 & 33 & 566 \\
\hline 6 & $F$ & 24 & 16 & 267 \\
\hline 7 & $\mathrm{~F}$ & 24 & 16 & 240 \\
\hline 8 & $\mathrm{~F}$ & 27 & 17 & 409 \\
\hline 9 & $F$ & NA & NA & NA \\
\hline 10 & $M$ & 30 & 28 & 680 \\
\hline 11 & $\mathrm{~F}$ & 32 & 34 & 789 \\
\hline 12 & $F$ & 34 & 22 & 635 \\
\hline 13 & $F$ & 44 & 5 & 50 \\
\hline
\end{tabular}

* Percent of lymphocytes staining with CD4 marker.

† Absolute number/cubic mm of CD4-staining lymphocytes.

$\ddagger$ NA, not available.

UCLA Human Subjects Protection Committee and with informed consent by blood donor or guardian.

Materials. Percoll used in cell separation was from Pharmacia Fine Chemicals, Uppsala, Sweden. For the SO assay, ferricytochrome $c$, superoxide dismutase, HRPO (salt-free powder), and PMA were all obtained from Sigma Chemical Co., St. Louis, MO. HBSS without phenol red and minimal essential medium were from Irvine Scientific, Santa Ana, CA. BCA Protein Assay Reagent was obtained from Pierce Co., Rockford, IL. For the HP assay, phenolsulfonphthalein (phenol red, sodium sait), $\mathrm{NaOH}$, and HP were from Sigma Chemical Co.. PRS for the HP assay was made with $140 \mathrm{mmol} / \mathrm{L} \mathrm{NaCl}, 10 \mathrm{mmol} / \mathrm{L}$ potassium phosphate buffer, pH 7.0, $5.5 \mathrm{mmol} / \mathrm{L}$ dextrose, $0.56 \mathrm{mmol} / \mathrm{L}$ phenol red, and $19 \mathrm{U} / \mathrm{mL}$ of HRPO. The Dynatech MR700 microplate reader was from Dynatech Laboratories, Inc., Chantilly, VA.

Cell separation. Separation of PMN and MNC was accomplished on Percoll gradients (12). Peripheral blood from normal volunteers and patients was anticoagulated with EDTA $(0.3 \%$ final concentration) and layered over discontinuous Percoll gradients. The blood was centrifuged for $20 \mathrm{~min}$ at $4^{\circ} \mathrm{C}$, resulting in two layers of cells with the first layer consisting of monocytes and lymphocytes (MNC) and the second layer (PMN) consisting of $>95 \%$ neutrophils with the remainder being eosinophils. The cells were washed in buffer and hypotonic lysis was used to remove erythrocytes from the PMN layer. The cells were resuspended in minimal essential medium (without protein) and then incubated in 96-well flat-bottom microplates (Falcon, 3072, Bec- ton Dickinson Labware, Lincoln Park, $\mathrm{NJ}$ ) at $37^{\circ} \mathrm{C}$ for $2 \mathrm{~h}$ in a $\mathrm{CO}_{2}$ incubator before assay (PMN $10^{5} /$ well. MNC $5 \times 10^{5} /$ well). SO assay: SO release was measured by reduction of cytochrome $c$. The assay follows the technique as outlined by Pick and Mizel (13). The Dynatech MR700 microplate reader was used for reading and recording absorbance changes. For the SO assay, an interference filter of $550 \mathrm{~nm}$ was used. After a $2-\mathrm{h}$ incubation in $5 \% \mathrm{CO}_{2}$ at $37^{\circ} \mathrm{C}$, nonadherent cells were removed by three washes with $0.1 \mathrm{~mL}$ of HBSS. The majority of PMN and monocytes adhere, whereas the lymphocytes are removed by the washings.

After incubation and removal of nonadherent cells, reagents dissolved in HBSS were then added to cell monolayers. The first vertical row of the microplate was used for the sample blank to which was added $0.1 \mathrm{~mL}$ of cytochrome $c(2 \mu \mathrm{g} / \mathrm{L})$ supplemented with superoxide dismutase $(300 \mathrm{ng} / \mathrm{L})$ to inhibit cytochrome $c$ reduction. The second vertical row contained cells with cytochrome $c$ alone. The third row contained cells with cytochrome $c$ and PMA $(0.1 \mathrm{ng} / \mathrm{L})$. The total volume in each well was 0.1 $\mathrm{mL}$. Readings were taken at $10,30,60$, and $120 \mathrm{~min}$ after the start of the incubation. Cells were incubated in $5 \% \mathrm{CO}_{2}$ at $37^{\circ} \mathrm{C}$ during the assay until the time of each reading.

The amount of SO per well was calculated from the absorption of the reduced cytochrome $c$ (third row, +PMA) minus the absorption of oxidized cytochrome (second row, -PMA). The absorption values in the first and second rows showed little variation $(<2 \%)$ meaning little spontaneous SO production without PMA. This would indicate that the cells were not activated by the separation or adherence procedures. The lack of spontaneous SO production was true using cells from either patients or controls, further indicating the patients' cells had not been activated in vivo. The corrected absorption value was inserted into the formula, absorbance at $550 \mathrm{~nm} / 6.3 \times 100=\mathrm{nmol}$ of SO. where 6.3 is the extinction coefficient (13). Protein content was also determined to account for variation in numbers of adhered cells per well. Triton-X (1\%) was added to each well and a protein assay was conducted the following day using the Lowry method with BSA as standard. There was not a significant difference in protein content between cells from controls and cells from HIV-infected patients. The results were then expressed in terms of $\mathrm{nmol}$ of $\mathrm{SO} / \mathrm{mg}$ of protein.

HP assay. HP was measured by HRPO-dependent oxidation of phenol red. The Dynatech MR700 microplate reader was used, fitted with a filter of $630 \mathrm{~nm}$. After removal of nonadherent cells, reagents were added. Using similar methodology, the first vertical row of the microplate served as the sample blank. PRS $(0.1 \mathrm{~mL})$ was added and then $0.01 \mathrm{~mL}$ of $\mathrm{NaOH}$ added to induce cell death and alkalinize the reaction mixture, eliminating changes in absorbance of phenol red due to its behavior as a $\mathrm{pH}$ indicator. In the second vertical row, PRS alone was added to cell monolayers. In the third row, PRS and PMA $(0.2 \mathrm{ng} / \mathrm{L})$ were added to the cells. Cells were then placed back into the $\mathrm{CO}_{2}$ incubator at $37^{\circ} \mathrm{C}$ for $90 \mathrm{~min}$.

After the incubation, $0.01 \mathrm{~mL}$ of $\mathrm{NaOH}$ was added to wells in the second and third rows to stop the reaction and readings were taken. Background HP (second row, -PMA) was subtracted again from the stimulated HP production (third row, +PMA) to obtain a corrected value. Using dilutions of HP solution of known concentration as outlined by Pick and Mizel (13), a standard curve can be obtained. As a result, absorbance values could be matched graphically to concentrations of HP. As with the SO assay, protein content in each well was determined to account for the variation in number of adhered cells. Results were then expressed in $\mathrm{nmol}$ of $\mathrm{HP} / \mathrm{mg}$ of protein. There was little spontaneous production of HP in the absence of PMA using cells from either controls or patients.

Statistical methods. Significance was determined by paired $t$ test unless otherwise stated, and all data was expressed as mean \pm SEM. $p$ values $<0.05$ were considered statistically significant. 


\section{RESULTS}

$H I V$-infected children versus controls. SO production by PMN and monocytes is shown in Figure 1 . The responses to PMA $(0.1$ $\mathrm{ng} / \mathrm{L}$ ) of $\mathrm{PMN}$ from normal adults and children were almost identical throughout the whole assay. In contrast, SO production by PMN from HIV-infected children was markedly depressed compared with that of the normal controls at all time points. By $2 \mathrm{~h}$, normal adult PMN had produced $1134 \pm 82 \mathrm{nmol} \mathrm{SO} / \mathrm{mg}$ protein and normal child PMN produced $1103 \pm 144 \mathrm{nmol} / \mathrm{mg}$ protein, whereas PMN from HIV-infected children generated only $701 \pm 64 \mathrm{nmol} / \mathrm{mg}$ protein. SO production by monocytes is illustrated in Fig. $1 B$. Generation of $\mathrm{SO}$ by monocytes from normal children was lower than that by monocytes from normal adults at most time points in contrast to the PMN data (Fig. $1 A$ ). However, monocytes from HIV-infected children generated less SO than did monocytes from normal adults at all time points and less than did monocytes from normal children at 10 and 30 min. The monocyte data for one patient with acute myelogenous leukemia (number 14, Table 1) was excluded because of difficulty in separating her MNC population. None of the MNC preparations from the other HIV-infected children had greater than $5 \%$ neutrophil contamination.

HP production by PMN from HIV-infected children was less than half that by PMN from normal adults and normal children (Fig. 2A). No difference was found in HP production between PMN from normal adults and normal children as had also been the case for SO production. Monocytes from normal children produced slightly lower levels of $\mathrm{HP}(136 \pm 31 \mathrm{nmol} / \mathrm{mg}$ protein $)$ compared with normal adults $(171 \pm 37 \mathrm{nmol} / \mathrm{mg}$ protein) as was noted previously in SO production by monocytes (Fig. 1B). However, monocytes from the HIV-infected children still produced less HP $(93 \pm 18 \mathrm{nmol} / \mathrm{mg}$ protein) than monocytes from either control group.

HIV-infected adults versus controls. Studies were conducted comparing the oxidative responses of PMN and monocytes from HIV-infected adults with those of uninfected adults. Many of these adult patients were mothers of infants who participated in

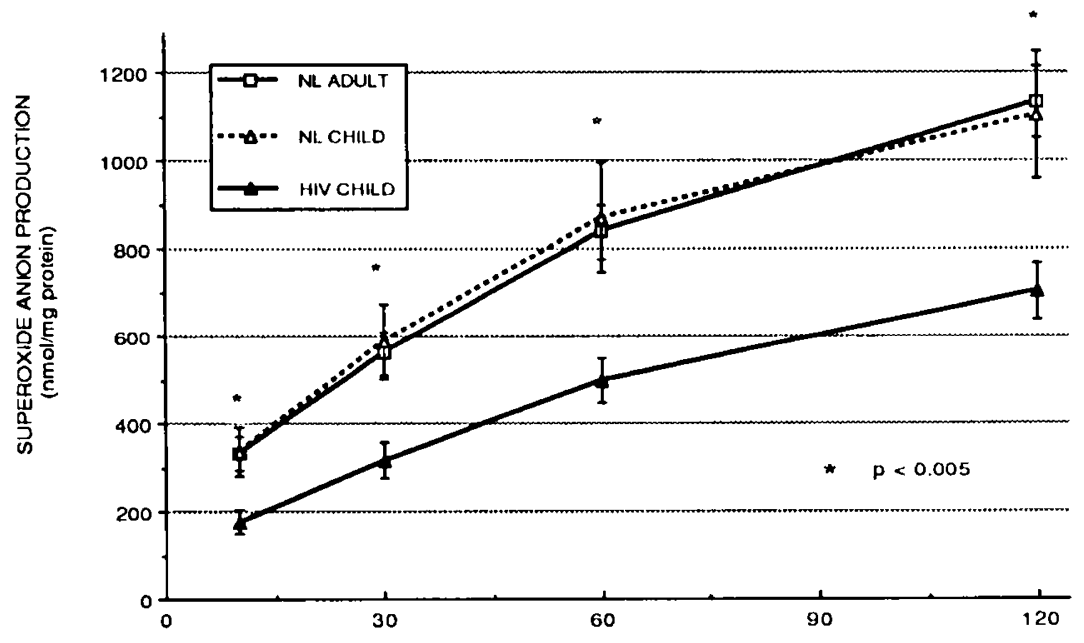

A.

INCUBATION TIME (min)

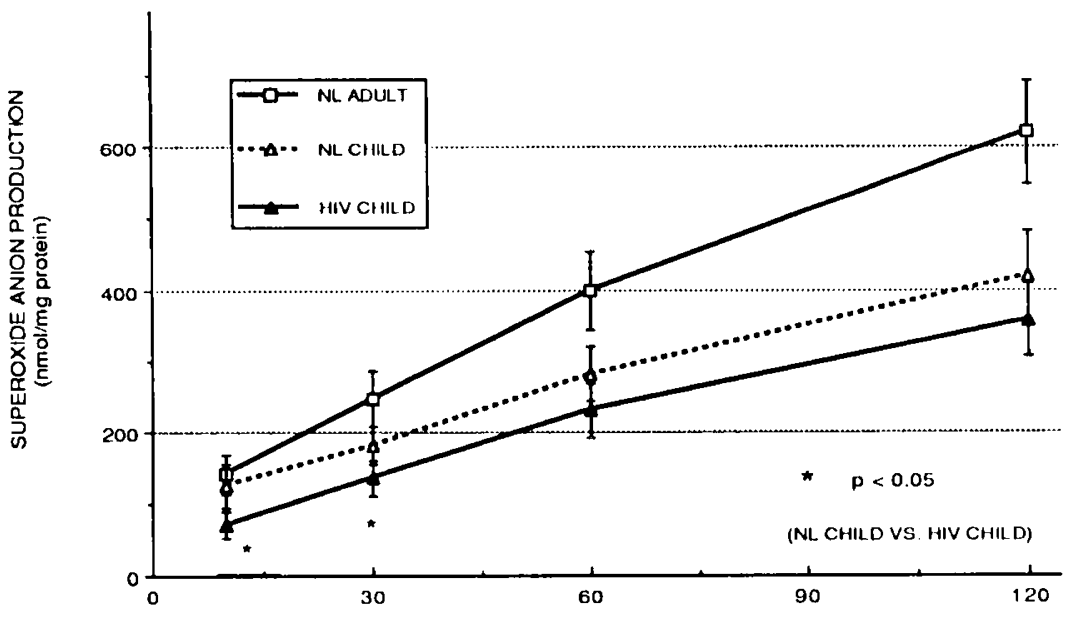

B.

Fig. 1. A. SO production by PMN from HIV-infected children. $B$, SO production by monocytes from HIV-infected children. The responses were measured over increasing incubation time and compared with the responses of cells from normal adults and children. SO production was stimulated by incubation in PMA (see text). 


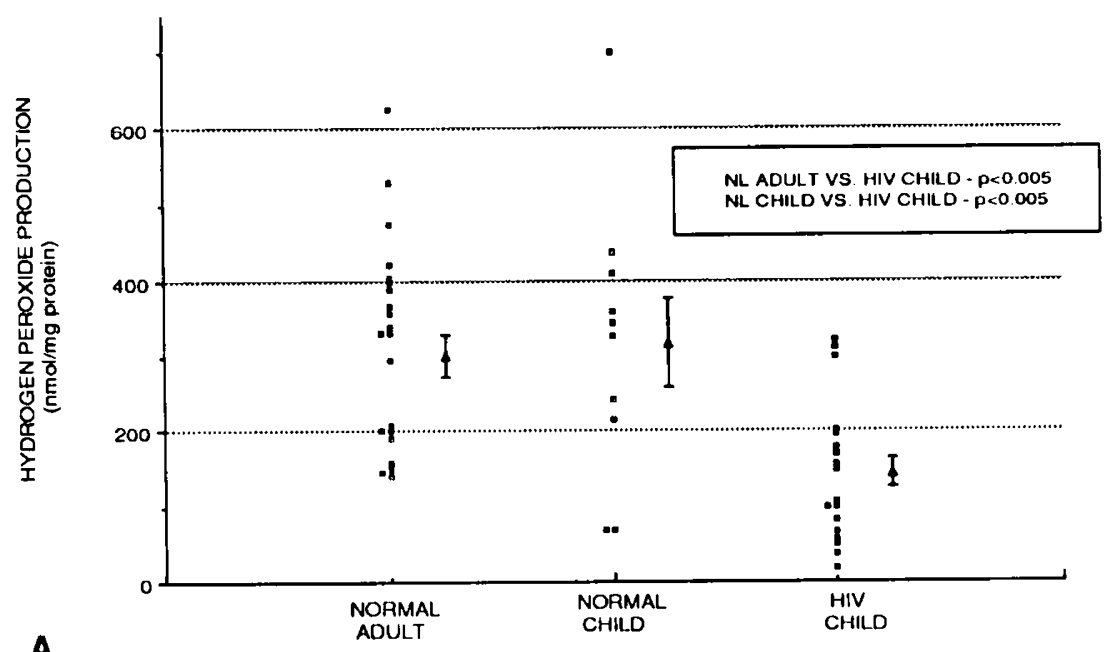

A.

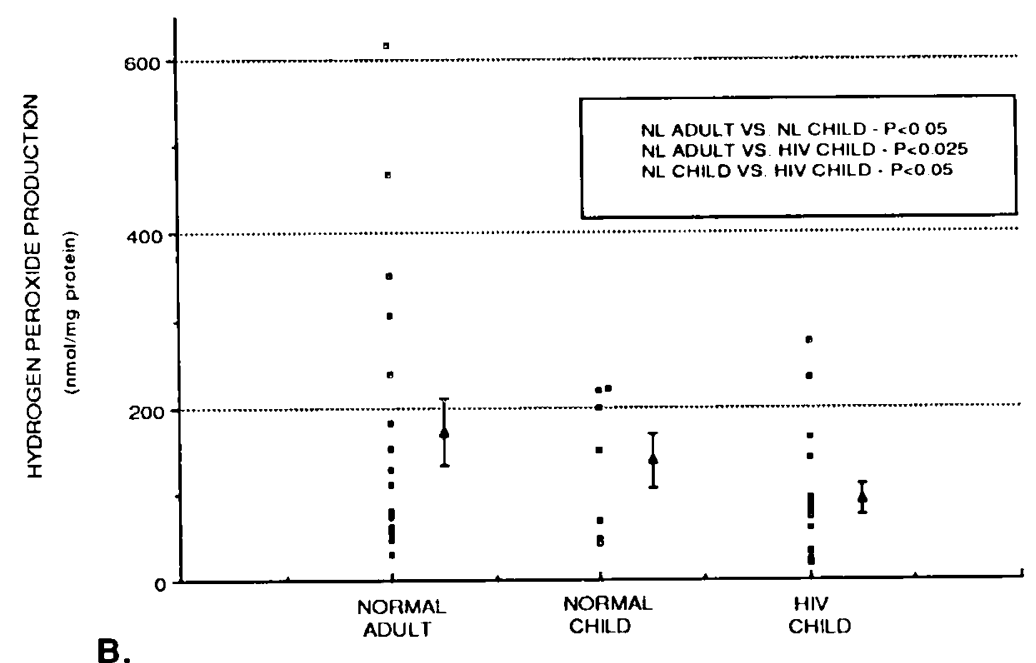

Fig. 2. $A$, HP production by PMN from HIV-infected children. $B$. HP production by monocytes from HIV-infected children. The responses were compared with the responses of cells from normal adults and children. HP production was stimulated by a 90-min incubation in PMA (see text). Triangles denote means with SEM.

the study. Data for these adult patients are shown in Table 1. Figure $3 A$ shows SO production by PMN from adults with HIV to be significantly lower than that of normal adults at all time points tested. Monocytes from HIV-infected adults (Fig. 3B) similarly produced lower levels of SO compared with monocytes from normal adults throughout the entire assay. This difference between cells from normal controls and HIV-infected patients was most apparent $(p<0.005)$ at $2 \mathrm{~h}$ for both PMN and monocytes.

Production of HP by PMN (Fig. 4) from HIV-infected adults $(208 \pm 30 \mathrm{nmol} / \mathrm{mg}$ protein) was also lower than that of PMN from normal adults ( $292 \pm 39 \mathrm{nmol} / \mathrm{mg}$ protein $)$. HP production by monocytes was less than that of PMN for both populations, but again the control monocytes had a higher response $(149+$ $25 \mathrm{nmol} / \mathrm{mg}$ protein) than the monocytes from HIV-infected patients $(105 \pm 21 \mathrm{nmol} / \mathrm{mg}$ protein). The monocyte data on one patient (patient number 1 , bottom half of Table 1), a 15-yold male, was not included because his MNC layer was found to contain 15\% neutrophils, which would have contaminated the monocyte preparation.

\section{DISCUSSION}

Our studies have shown SO and HP production by PMN from HIV-infected children were markedly decreased compared with PMN from normal children and normal adults. Monocytes from HIV-infected children were also deficient in SO and HP generation compared with normal adult and normal child monocytes, although the differences in the two child groups were not as great. SO and HP production by both monocytes and PMN from HIV-infected adults were also deficient compared with normal adults.

Previous studies have examined oxidative burst activity by phagocytic cells in HIV infection. Murphy et al. (14) found SO production by PMA-stimulated PMN from adults with HIV to be higher compared with PMN from normal adults, but the assay ran for only $10 \mathrm{~min}$. Our assays were read over a 2 -h period and the differences between normal and HIV PMN were greatest at 2 h. Roilides et al. (5) reported a similar study that found SO generation by PMN from HIV-infected children the same as that of age-matched controls, but the incubation period was only 5 min. Nielson et al. (15) also found no difference between controls 


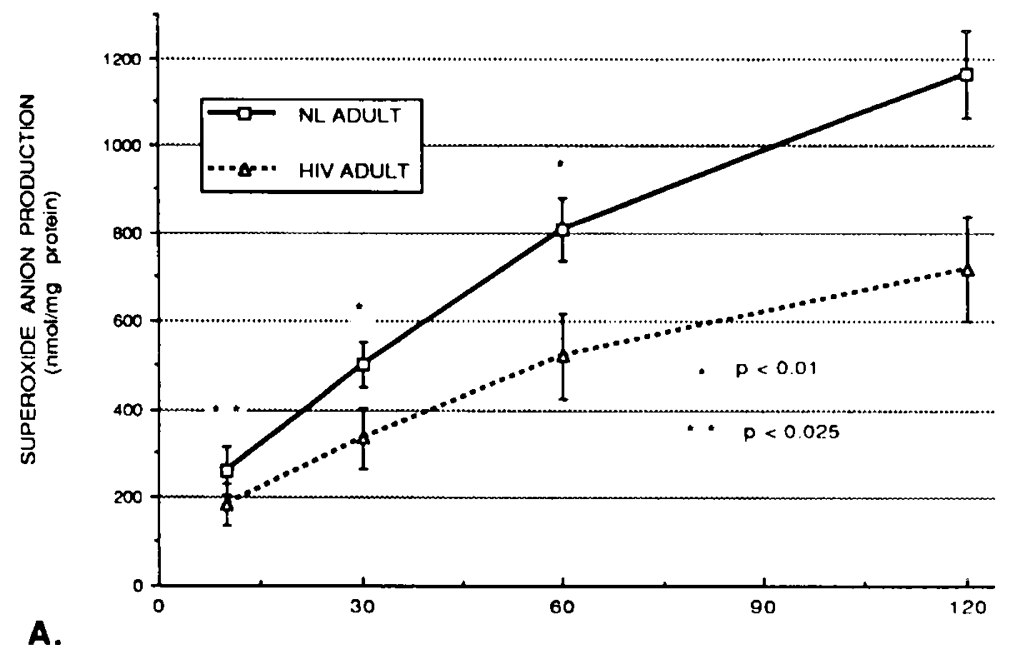

A.

INCUBATION TIME (min)

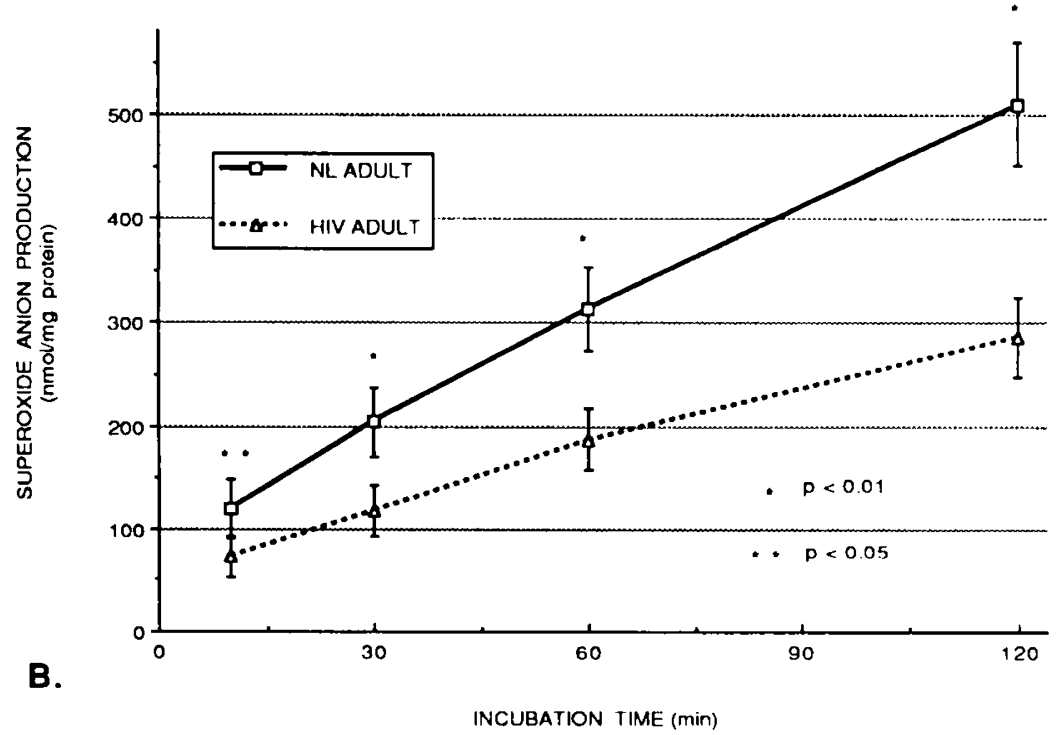

Fig. 3. $A$, SO production by PMN from HIV-infected adults. $B$, SO production by monocytes from HIV-infected adults. The responses were measured over increasing incubation time and compared with the responses of cells from normal adults. SO production was stimulated by incubation in PMA (see text).

and HIV patients in SO production by PMN $(n=4)$ and monocytes $(n=6)$, but only the rate of SO production was reported. Another factor that may explain these results is that the previous investigators were testing cells in suspension, whereas the cells in our studies were adhered to plastic.

Other investigators have reported the oxidative burst activity of PMN in HIV-infected adults to be decreased. Stohr et al. (16) found the chemoluminescence response to concanavalin $A$ of PMN from AIDS patients to be greatly reduced compared with normal controls. Reduction of NBT by PMN stimulated with heat-killed bacteria in a 30 -min assay was reported to be decreased in AIDS patients but increased in ARC patients (17). NBT reduction by PMN was also found to be inhibited by exposure to soluble HIV proteins, particularly gp41 (18).

The role of monocytes and macrophages in HIV infection has been more extensively studied than that of PMN because the virus is able to reside and replicate in these monocytic cells. The chemoluminescence response to zymosan of peripheral blood monocytes from asymptomatic HIV-infected adults and AIDS patients was reported to be decreased in those individuals whose serum was positive for p24 antigen (19). Muller et al. (20) assessed NBT reduction by monocytes and monocyte-derived macrophages in asymptomatic HIV-infected men and AIDS patients. They found NBT reduction as stimulated by PMA and zymosan to be impaired in both groups compared with controls. A more recent study also found the chemoluminescence response to zymosan of peripheral blood monocytes from HIV-infected patients to be lower than that of controls in a $60-\mathrm{min}$ assay (9). Alveolar macrophages from pediatric ARC patients were reported to release more $\mathrm{HP}$ at both baseline levels and after stimulation with PMA $(5 \mathrm{ng} / \mathrm{L})$ than a control group, although the assay was run for only $30 \mathrm{~min}$. (21). Our HP assay using monocytes ran for $90 \mathrm{~min}$.

Other studies have reported defects in monocytes from HIVinfected patients in cytotoxicity and intracellular killing in which ROI production may play a role. The monocyte candidacidal activity for Candida pseudotropicalis in HIV-infected patients was reported to be impaired and deteriorated further in patients with more advanced disease (9). Monocyte-derived macrophages infected with HIV in vitro were also reported to be defective in 


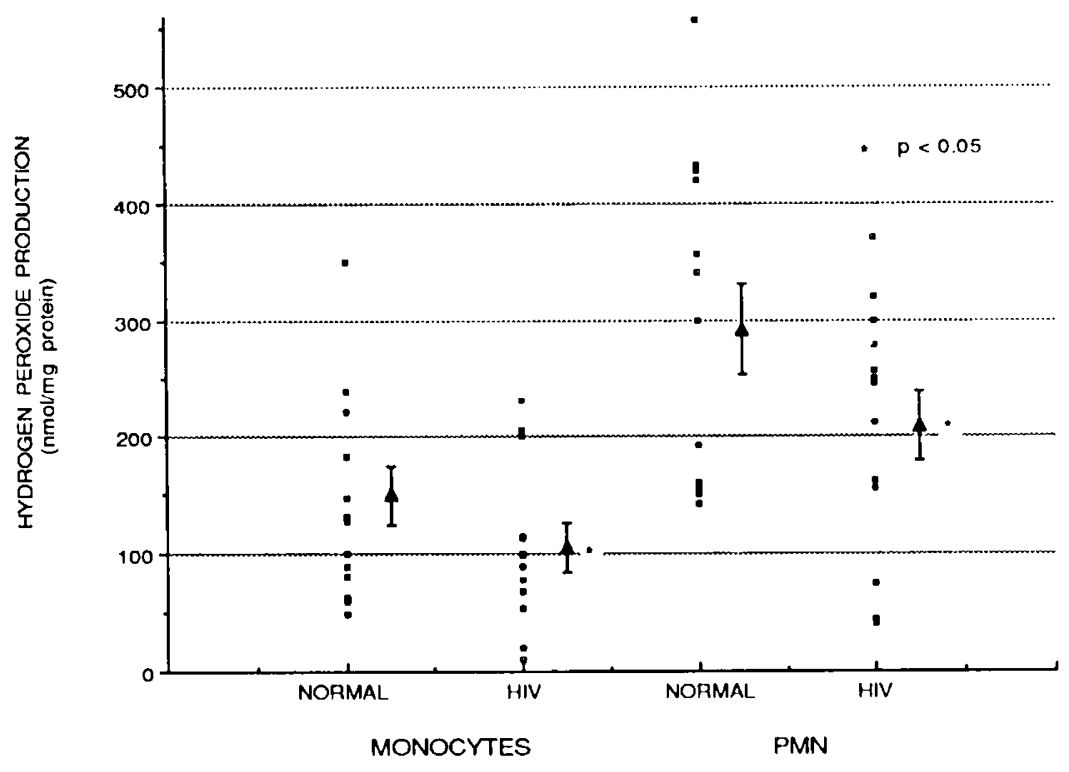

Fig. 4. HP production by monocytes and PMN from HIV-infected adults compared with that of cells from normal adults. Assay was run for 90 min after stimulation with PMA (see text). Triangles denote means with SEM.

killing $C$. pseudotropicalis (22). Monocytes from ARC patients had decreased ability to phagocytose and kill Staphvlococcus aureus, although no defect was noted in asymptomatic HIVinfected patients (23). Bender et al. (6) found that the ADCC of monocytes from AIDS patients was lower than that of monocytes from normal controls. Our laboratory recently reported that ADCC of both PMN and monocytes from HIV-infected children and adults to be lower than that of controls using CEM cells coated with HIV gp 120 protein in the presence of anti-HIV sera (3).

Our results indicate oxidative burst activity is impaired in both PMN and monocytes from HIV-infected children and adults. Monocytes can be infected by HIV, and it is possible that HIV infection directly interferes with the ability of the cell to make oxygen intermediates. However, no evidence of incorporation of HIV in the genome of mature neutrophils was found by Spear et al. (24). Because the virus does not infect the neutrophil or its myeloid precursors, it is necessary to postulate other mechanisms to account for the defect in PMN.

Another possibility is that serum factors in HIV infection affect neutrophil and monocyte function. HIV viral proteins, particularly gp 41 , have been reported to inhibit both PMN and monocyte chemotaxis and oxidative burst activity $(17,25)$. Alterations of various cytokine levels in HIV infection may also influence phagocyte function. However, the persistence of defects in the absence of HIV serum suggests an intrinsic defect in the phagocytic cells themselves.

Chronic bacterial and fungal infections in HIV patients result in prolonged stimulation of their neutrophils and monocytes. This chronic stimulation leads to release of ROI from phagocytic cells. This persistent ROI production can deplete leukocytes of intracellular glutathione, resulting in dysfunction of lymphocytes and PMN and in enhanced replication of HIV in infected macrophages (26-28). Decreased levels of glutathione, an important oxygen scavenger, have been reported in the serum and in lymphocytes of HIV-infected patients $(29,30)$. It is possible that this decreased ability of PMN and monocytes from HIV patients to protect themselves from their own ROI due to low glutathione stores results in impaired function or decreased viability in the longer assays as reported in this study.

Children with HIV infection are more prone to bacterial infections than adults, leading to greater stimulation of their phagocytic cells and consequently greater release of ROI. Newborn infants are particularly vulnerable to ROI because their levels of oxygen scavenging enzymes are lower than those of adults (31). Thus, infants and children with HIV infection may be more susceptible to oxidative injury than infected adults. Impaired function of phagocytic cells due to oxidative injury makes them more prone to further bacterial infections, thus resulting in a vicious cycle of infection and $\mathrm{ROI}$ release.

Our studies have shown that both PMN and monocytes from HIV-infected children and adults are defective in release of SO and HP and that these deficits are more apparent as the cells are stimulated over increasing periods of time. This defect in oxidative burst activity may account in part for the increased susceptibility to bacterial and fungal infections.

\section{REFERENCES}

1. Valone FH. Payan DG. Abrams DJ. Goetzl EJ 1984 Defective polymorphonuclear leukocyte chemotaxis in homosexual men with persistent lymph node syndrome. J Infect Dis 150:267-27

2. Kinne TJ, Gupta S 1989 Antibody-dependent cellular cytotoxicity by polymorphonuclear leukocytes in patients with AIDS and AIDS-related complex. J Clin Lab Immunol 30:153-156

3. Szelc CM. Mitcheltree C. Roberts RL Stiehm ER 1992 Deficient polymorphonuclear cell and mononuclear cell antibody-dependent cellular cytotoxicity in pediatric and adult human immunodeficiency virus infection. $J$ Infect Dis 166:486-493

4. Roilides E, Mertins S, Eddy J, Walsh TJ, Pizzo PA, Rubin M 1990 Impairmen of neutrophil chemotactic and bactericidal function in children infected with human immunodeficiency virus type 1 and partial reversal after in vitro exposure to granulocyte-macrophage colony-stimulating factor. J Pediat 117:531-540

5. Roilides E, Walsh TJ, Pizzo PA. Rubin M 1991 Granulocyte colony-stimulating factor enhances the phagocytic and bactericidal activity of normal and defective human neutrophils. J Infect Dis 163:579-583

6. Bender BS. Davidson BL. Kline R. Brown C. Quinn TC 1988 Role of the mononuclear phagocyte system in the immunopathogenesis of human immunodeficiency virus infection and the acquired immunodeficiency svndrome. Rev Infect Dis 10:1142-1154

7. Smith PD, Ohura K. Masur H. Lane HC. Fauci AS, Wahl SM 1984 Monocyte function in the acquired immune deficiency syndrome. J Clin Invest $74: 2121-2128$

8. Martin LS, Spira TJ, Orloff SL, Holman RC 1988 Comparison of methods for assessing chemotaxis of monocytes and polymorphonuclear leukocytes isolated from patients with AIDS or AIDS-related conditions. J Leukocyte Biol 44:361-366

9. Estevez ME, Ballart IJ, Diez RA, Planes N, Scaglione C, Sen L 1986 Early defect of phagocytic cell function in subjects at risk for acquired immunodeficiency syndrome. Scand J Immunol 24:215-221

10. Bravo-Cuellar A. Nowacki W. Vuillier F. Saint-Martin J, Orbach-Arbouys S 1992 The bactericidal capacity of peripheral blood monocytes from HIV positive patients may collapse very soon after the infection. Immunol Lett 31:297-300

11. Prince HE. Moody DJ. Shubin BI, Fahey JL 1985 Defective monocyte function 
in acquired immune deficiency syndrome (AIDS): evidence from a monocyte-dependent T-cell proliferative system. J Clin Immunol 5:21-25

12. Roberts RL, Ank BJ, Stiehm ER 1991 Human eosinophils are more toxic than neutrophils in antibody-independent killing. J Allergy Clin Immunol 87:1105-1115

13. Pick E, Mizel D 1981 Rapid microassays for the measurement of superoxide and hydrogen peroxide production by macrophages in culture using an automatic enzyme immunoassay reader. J Immunol Methods 46:211-226

14. Murphy PM, Lane HC, Fauci AS, Gallin JI 1988 Impairment of neutrophil bactericidal capacity in patients with AIDS. J Infect Dis 158:627-630

15. Nielson H, Kharami, Faber V 1986 Blood monocyte and neutrophil functions in the acquired immune deficiency syndrome. Scand J Immunol 24:291296

16. Stohr L, Sessler MJ. Altmeyer P, Scharrer I, Holzman H, Stille W, Helm EB, Elbert M, Gurenci J 1984 Phagocytotic and metabolic activity of granulocytes in AIDS-. lymphadenopathy- and hemophilia patients. In: Kricka LJ (ed) Analytical Applications of Bioluminescence and Chemiluminescence. Academic Press, San Francisco, pp 451-454

17. Sonnerborg A, Jarstrand C 1986 Nitroblue tetrazolium (NBT) reduction by neutrophilic granulocytes in patients with HTLV-III infection. Scand J Infect Dis 18:101-103

18. Gabrilovich DI, Kozhich AT, Suvorova K, Ivanov VS, Moshnikov SA, Chikin LD, Kolezunkova OV, Pokrovsky VV 1991 Influence of HIV antigens on functional activity of neutrophilic granulocytes. Scand J Immunol 33:549_ 552

19. Braun DP, Kessler H. Falk L. Paul D, Harris JE. Blaauw B, Landay A 1988 Monocyte functional studies in asymptomatic, human immunodeficiency disease virus (HIV)-infected individuals. J Clin Immunol 8:486-494

20. Muller F, Rollag G, Froland SS 1990 Reduced oxidative burst in monocytes and monocyte derived macrophages from HIV-infected subjects. Clin Exp Immunol 82:10-15

21. Clement A, Sardet A. Chadelat K, Grimfeld A, Tournier G 1988 Activation of alveolar macrophages from children with the acquired immunodeficiency syndrome-related complex. Pediatr Pulmonol 5:192-197

22. Baldwin GC, Fleischmann J, Chung Y, Koyanag Y, Chen ISY, Golde DW 1990 Human immunodeficiency virus causes mononuclear phagocyte dysfunction. Proc Natl Acad Sci USA 87:3933-3937

23. Szkaradkiewicz A 1992 Phagocytosis and microbicidal capacity of human monocytes in the course of HIV infection. Immunology Lett 33:145-150

24. Spear GT, Ou CY. Kessler HA. Moore JL. Schochetman G. Landry AL 1990 Analysis of lymphocytes. monocytes, and neutrophils from human immunodeficiency virus (HIV)-infected persons for HIV DNA. J Infect Dis 162:1239-1244

25. Tas M. Drexhage HA, Goudsmit J 1988 A monocyte chemotaxis inhibiting factor in serum of HIV infected men shares epitopes with the HIV transmembrane protein gp41. Clin Exp Immunol 71:13-18

26. Buhl R, Holroyd KJ, Mastrangeli A, Cantin AM, Jaffe HA, Wells FB, Saltini C, Crystal RG 1989 Systemic glutathione deficiency in symptom-free HIV. seropositive individuals. Lancet 2:1294

27. Kalebic T, Kinter A, Poli G, Anderson ME, Meister A. Fauci AS 1991 Suppression of human immunodeficiency virus expression in chronically infected monocytic cells by glutathione, glutathione ester, and $\mathrm{N}$-acetylcysteine. Proc Natl Acad Sci USA 88:986-990

28. Suthanthiran M, Anderson ME. Sharma VK. Meister A 1990 Glutathione regulates activation-dependent DNA synthesis in highly purified normal human T lymphocytes stimulated via the CD2 and CD3 antigens. Proc Natl Acad Sci USA 87:3343-3347

29. De Quay B, Malinverni R, Lauterburg BH 1992 Glutathione depletion in HIVinfected patients: role of cysteine deficiency and effect of oral $\mathrm{N}$-acetylcysteine. AIDS 6:815-819

30. Baruchel S. Wainberg MA 1992 The role of oxidative stress in disease progression in individuals infected by the human immunodeficiency virus. J Leukocyte Biol 52:111-114

31. Strauss RG, Snyder EL, Wallace PD, Rosenberger TG 1980 Oxygen-detoxifying enzymes in neutrophils of infants and their mothers. J Lab Clin Med 95:897-904 